\title{
9 The Coordination of COVID-19 Responses in Malaysia
}

\author{
Efforts and Challenges
}

Nurliana KAMARUDDIN and Zokhri IDRIS

\begin{abstract}
Historically, Malaysia has demonstrated good, coordinated strategies in dealing with disease outbreaks. However, COVID-19 has been larger in scale than previous pandemics and the country was in the midst of political upheaval when the first case was detected in the country. This chapter examines the coordination between political actors and analyses the challenges Malaysia faced as a result of the outbreak, specifically regarding the treatment of migrant workers and strict border controls. It highlights the country's need for consistent policies for workers and shows that Malaysia needs to balance health security, political stability, and economic growth in order to successfully manage the pandemic.
\end{abstract}

Keywords: Malaysia, health security, political stability, public health, COVID-19

\section{Introduction}

When the first COVID-19 case was detected in Malaysia on 4 February 2020, the country was in the middle of political unrest. The historic change of Malaysia's ruling coalition that occurred in the 2018 general election, from Barisan Nasional (BN) to Pakatan Harapan (PH), had lasted for a mere two years. Then $\mathrm{PH}$ fell apart due to infighting and changing party allegiances. Following the withdrawal of BERSATU (one of the parties that made up the ruling coalition) from $\mathrm{PH}$ on 23 February 2020, PH no longer held a majority

\footnotetext{
Van der Veere, Anoma P., Florian Schneider, and Catherine Yuk-ping Lo (eds), Public Health in Asia during the COVID-19 Pandemic: Global Health Governance, Migrant Labour, and International Health Crises. Amsterdam, Amsterdam University Press 2022 DOI: 10.5117/9789463720977_CHo9
} 
of parliamentary seats. This led to the resignation of the then Prime Minister Mahathir Mohamad.

Between 24 and 28 February, Malaysia did not have a Prime Minister or cabinet members. Muhyiddin Yassin, then Minister of Home Affairs, was appointed Prime Minister by the King on 1 March 2020. Other cabinet members were sworn in on 7 March, after there had been no cabinet members in office for fourteen days. As a result, Malaysia witnessed a lack of coordination in infectious disease control, leading to a spike where there were 25 cases of COVID-19 in February (Ministry of Health Malaysia 2020a). Despite the country losing ground during the initial stage of the outbreak, the newly formed government was quick to implement measures, prioritizing testing, tracing, and containment.

This chapter will examine the Malaysian government's actions in tackling the COVID-19 crisis. It will first examine the coordination between political actors and civil servants, including health and security practitioners, as well as the economic support provided by the government. It will then examine the challenges Malaysia has faced as a result of the outbreak as well as the policies implemented to contain the virus. Finally, it will conclude by discussing how Malaysia might move forward in these uncertain times.

\section{Coordinating Public Services during the Pandemic}

Malaysia's first COVID-19 cases were detected when three out of eight Chinese nationals entering the southern state of Johor Bahru tested positive on 25January 2020. The first major cluster of local cases came from a religious gathering that was held in the suburb of Sri Petaling (Kanyakumari 2020). Since the Islamic gathering had over 16,00o attendees, the government took urgent measures when the first case from this cluster was found on 11 March. To contain the outbreak, the Malaysian government needed to efficiently coordinate across various ministries and agencies.

Before COVID-19, Malaysia had experienced several other infectious disease outbreaks and the authorities had demonstrated an effective capacity to deal with the past smaller-scale outbreaks. In 1996, a major cholera outbreak hit the northern state of Penang. The authorities reported a total of 1182 cases and detected 231 carriers, but the outbreak resulted in zero deaths. In 1997, the Malaysian state of Sarawak reported an outbreak of Hand, Foot and Mouth Disease (HFMD). This resulted in 31 deaths, a total that was relatively low in proportion to the number of deaths worldwide. Two years later, Malaysia also saw an outbreak of Nipah Encephalitis that 
resulted in 283 recorded cases and 109 deaths. In 2001, Malaysia experienced an Anthrax scare attributed to a bioterrorist attack. There were 136 reported cases with no fatalities. Considering these events, the Malaysian government and its Ministry of Health had a proven track record in handling infectious diseases prior to the COVID-19 pandemic. The government had demonstrated excellent coordination in containing diseases and preventing them from reaching larger groups of Malaysian residents.

COVID-19 nevertheless has presented a different dynamic. The Minister of Health, under the Prevention and Control of Infectious Diseases Act (PCID) 1988, declared that COVID-19 was a national outbreak. Under the PCID, when a disease is classified in this way it requires the active intervention of the authorities. That said, COVID-19's characteristics show no similarity to previous infectious diseases. The former has a fast-spiralling effect where individuals can be infected either through air-borne water droplets or through physical contact with people or objects contaminated with the virus. The rapid escalation of infection led to the Malaysian government declaring COVID-19 a national disaster. ${ }^{1}$ This declaration took into account the exponential growth of infection globally. The labelling of COVID-19 as a national disaster for Malaysia meant that proactive government intervention was required to stop the spread of the outbreak. Since 1969, the country has not undergone any other catastrophe that has required government intervention at the national level.

The Malaysian National Security Council (NSC) activated an emergency structure to combat COVID-19. On 18 March 2020, Malaysia imposed a nationwide Movement Control Order (MCO). The measure was intended to limit citizens' movements in order to break the chain of infections. Businesses were required to close except for essential services, and the general public were only allowed limited travel. Interstate travel was prohibited and any areas with more than 40 cases were considered red zone areas and were cordoned (Tang 2020). Malaysia also enforced strict quarantine measures for those travelling into the country and prohibited any form of mass gatherings. These measures were all strictly enforced, first by the police and later with the assistance of the military (Loh 2020).

The NSC, which is chaired by the Prime Minister, has convened frequently to receive reports, analyse possible actions, and prepare a standard operating procedure for all citizens and other Malaysian residents. This standard

1 Under Directive No.20 of National Security Council (MKN 20), a disaster is defined as 'an incident that occurs without warning, complex in nature and results in loss of lives, property and damage to the environment.' 
Table 9.1 Daily reported cases from 25 September to 12 October 2020

\begin{tabular}{lcc}
\hline Date (2020) & New cases & Total active cases \\
\hline 25 September & 111 & 858 \\
26 September & 82 & 851 \\
27 September & 150 & 950 \\
28 September & 115 & 1,011 \\
29 September & 101 & 1,062 \\
30 September & 89 & 1,121 \\
1 October & 260 & 1,334 \\
2 October & 287 & 1,540 \\
3 October & 317 & 1,735 \\
4 October & 293 & 1,961 \\
5 October & 432 & 2,336 \\
6 October & 691 & 2,936 \\
7 October & 489 & 3351 \\
8 October & 375 & 3351 \\
9 October & 354 & 3863 \\
10 October & 374 & 4161 \\
11 October & 561 & 4587 \\
12 October & 563 & 5039 \\
\hline
\end{tabular}

Source: Ministry of Health, Malaysia 2020c.

operating procedure has then been communicated to the public by the Senior Minister of Defence through a televised briefing at 14:00 hrs each day (during the first period of the Movement Control Order [MCO]). The Ministry of Health, through its director-general, has also televised reports about the number of new cases, existing cases, and deaths at 17:0o hrs each day. According to the modelling and forecasting conducted by the National Institute of Health, the MCO effectively controlled the transmission of COVID-19 (Ministry of Health 2020b). The transmission rate decreased from the alarming three-digit figures seen in the early months to single-digit figures in the months after that until the end of September. The success of the MCO and the subsequent decline of infection rates allowed the government to slowly ease the MCO. On 4 May 2020 it implemented the Conditional Movement Control Order (CMCO) and then on 10 June it implemented the Recovery Movement Control Order (RMCO). These two orders saw the gradual loosening of prohibited activities. Businesses could operate as long as they followed the standard operating procedures (SOP). ${ }^{2}$

2 Some examples of these SOPs include businesses having only $30 \%$ of their essential operation teams on the premises. Non-essential staff members were instructed to work from home. Stores 
Despite this success story, Malaysia began to experience another spike of COVID-19 cases in late September 2020. On 25 September, the authorities reported a total of 111 cases. In the subsequent months, the country's daily reported cases consistently increased (see Table 9.1). The increase sparked fears of a third wave. Currently, with stringent contact tracing and targeted lockdown orders in place, the Malaysian government has expressed confidence that the situation is under control (Loheswar 2020).

Aside from controlling and monitoring the number of cases, the Malaysian government has also provided economic assistance for the affected populations as part of its COVID-19 measures. The government distributed Pakej Prihatin (loosely translated as 'Care Packages') in different stages to aid those Malaysians who had been economically affected by the outbreak. The first package was released on 26 February, which gave financial allowance to public healthcare workers, and also financial aid to households in the middle and bottom 40\% (known as $\mathrm{B}_{40}$ and $\mathrm{M}_{40}$ households). Households and individual earners were awarded RM10oo to RM16oo (approximately USD $\$ 250$ to USD \$400) and RM250 to RM500 (approximately USD \$6o to USD\$125) respectively, according to their projected income (Prime Minister's Office 2020a).

Subsequently, the government released an additional Prihatin package on 6 April. These funds were intended to help small and medium enterprises (SMEs) to retain employees and avoid business closures. Following a series of consultations with financial institutions, the authorities announced special packages to aid retrenched employees and locally-based SMEs. On $29 \mathrm{July}$, the government extended a previous loan moratorium for retrenched citizens by a further three months. Employed citizens who have received pay cuts as a result of COVID-19 have also been able to negotiate with their banks on payment adjustments. Meanwhile, SMEs have been allowed to pay interest to their banks at a later time, to extend their loan periods, as well as to receive other payment exemptions that are reasonable to both parties (Prime Minister's Office 202ob).

\section{Issues and Challenges}

Handling a global pandemic can prove challenging even for the most advanced nations. The COVID-19 pandemic shows that economic strength does 
not equate to effective governance in dealing with the outbreak. Malaysia has faced its share of challenges in its effort to combat the pandemic: the government has to deal with domestic issues, such as a lack of compliance by some sectors as well as inconsistencies in policy announcement and enforcement. In Malaysia, one of the biggest challenges that the pandemic has caused is linked to the issue of controlling the movement and migration of people. This section will explore two major challenges that Malaysia faces. The first is the way that cases involving foreigners have been linked to the larger issue of illegal migration, raising questions about how migrants are treated in Malaysia. The second concerns the implications stemming from the extended entry restrictions that Malaysia enacted.

On 18 September 2020, Malaysia recorded 21 new cases, of which only one case involved a non-Malaysian. This positive turn of events however was preceded by a tumultuous period where a large number of cases had been found amongst groups of low-skilled migrant workers. Between April and May 2020, clusters of infection were traced back to migrant workers ranging from security guards to construction workers (Code Blue 2020). For example, the Ministry of Health disclosed on 25 April 2020 that from 14,187 foreign workers who were tested, 676 had tested positive for COVID-19. This was followed with the disclosure on 1 June 2020 that 2014 individuals out of 35,811 non-citizens tested were found to be COVID-19 positive (Tan, Mohd Noor, and Khalidi 2020).

The organization Business and Human Rights Resource Centre (2020) warned about the relatively high exposure of migrant workers to COVID-19, in particular among those working in unhygienic environments, such as those categorized as working in ' $3 \mathrm{D}$ ' employment, meaning that which is dangerous, dirty, and difficult (Sukumaran 2020). The low standards of living in the communities of migrant workers could also be problematic in relation to their exposure to COVID-19. Residences are usually crowded in construction areas, which cram workers into small units. Poor sanitation and inadequate sewage systems impact the living condition of foreign workers and thus increase their likelihood of infection.

To contain the spread of the virus, the Malaysian government has increased immigration raids, made testing mandatory for migrant workers, and prohibited the hiring of new foreign workers (Babulal 2020). The news organization Al Jazeera produced a documentary about the Malaysian government's treatment of migrants during the pandemic, criticizing what it saw as draconian measures which included inhuman conditions of detention and deportation (Al Jazeera 2020). In response, the Malaysian authorities deported a Bangladeshi worker interviewed in the documentary 
and investigated the news agency for defamation and sedition (Rodzi 2020). There has been a mixed reaction to the documentary and the government's response. Some news media have accused the Malaysian government of being authoritarian and anti-freedom-of-speech (Peter 2020; Smith 2020). Others have given the government their support. They state that the news channel purposely misrepresented the government. They argued that claims that the government's actions were racist misconstrued these actions and that the government's measures have been based on containing the virus and not on any racial discrimination (Yunus 2020; Malay Mail 2020).

Malaysia has covered the costs of COVID-19 testing for all the workers whose employers contribute to the national social security organization (New Straits Times 2020). The Malaysian government has also continued to provide medical care for all migrant workers infected with the virus, regardless of their immigration status. The government likewise prepared a 6oo-bed quarantine facility specifically for migrant workers (Landau 2020). It declared that those workers who were found to be in the country illegally would be deported after treatment (Kaos and Sivanandam 2020). There have also been repeated calls from the Ministry of Health's directorgeneral to ensure that there is no discrimination in the treatment provision (Hermesauto 2020).

Alongside the testing subsidies, financial aid from the government arguably has not reached the bulk of foreign workers as the aid has mostly been channelled to SMEs owned by Malaysians and employing Malaysian citizens. The employment of migrant workers in Malaysia is largely concentrated in large-scale construction firms and restaurants, with a group of migrant workers also employed in individual households as domestic helpers. Migrant workers who were employed on construction sites and in restaurants were seriously affected by the MCO because of temporary closures. Most of the companies in these two industries are not SMEs but larger corporations which have not been fully covered by the Prihatin economic assistance. In all cases, the Malaysian government's financial packages have not reached migrant workers directly. As such, migrant workers' livelihoods have largely depended on the performance of their employers in weathering the pandemic.

Leaving aside the debate about whether Malaysia has been unfair in its treatment of illegal migrant workers, the pandemic has revealed major problems with the status quo in Malaysia. Malaysia's dependency on foreign workers for low skilled jobs means that the government has been inconsistent in handling the issue of undocumented workers in the country. Besides, Malaysia has no separate official policy on refugees and asylum seekers, 
leading to a sizable number of unregistered migrants in the country. The conditions of immigration detention centres for arrested illegal migrants are poor, with migrants kept in close and cramped quarters (Global Detention Project 2020).

The COVID-19 pandemic has highlighted the fact that Malaysia needs a major overhaul of its labour and migration laws in order to lessen its dependency on cheap foreign labour and provide better protection for both local and foreign workers in case another pandemic occurs. The International Labour Organization has provided suggestions concerning migrant workers (Sandanasamy, Paavilainen, and Baruah 2020). This includes the observation that one of the best ways to get undocumented migrants to voluntarily come for testing and treatment during the outbreak is to ensure that there is no fear of detainment and that costs are subsidised or borne by the government. At the same time, the enforcement of labour laws still needs to be upheld.

Malaysia's decision to enact stricter border controls as a means to control the pandemic has had economic and political implications for the country. One economic implication is the impact on tourism. Tourism, which is a big contributor to the Malaysian economy, has been one of the industries hardest hit by the pandemic. At the time of writing (September 2020), Malaysia had extended the travel ban on foreign tourists until the end of December 2020. On 7 September, it also introduced an entry prohibition for countries with over 150,000 cases. The list includes 23 countries, such as the United States, Brazil, and India. The travel ban grants exemption only to diplomatic travellers, while barring students and workers and spouses with long term visas from entering the country for an indefinite period.

The decision has not been a popular one. The government has received appeals from various sectors and especially from members of the business community such as the American Malaysian Chamber of Commerce (Bernama 2020; The Star 2020). It has also received appeals from local investment promotion agencies (Lim 2020). These agencies point out that the entry restrictions not only impact immediate economic growth and employment but could likewise have more far-reaching consequences, such as a loss of trust in the reliability of Malaysia as a trade partner and place of business. Malaysia's government needs to consider the loss of overseas expertise that companies based in Malaysia depend on.

Similarly, the travel ban may impact other sectors. Restricting international students coming into the country may also affect universities and the attractiveness of Malaysia as a hub for higher education. In addition, Malaysia is known as a medical tourism destination, and thus the travel ban could have consequences in this industry. There are fears that the 
pandemic might mean that Malaysia would enforce tighter border controls. As a country that is dependent on foreign workers, this could lead to an increase in illegal migration instead. Such a phenomenon would potentially compound some of the problems that Malaysia is already facing and that have been discussed earlier in this chapter

Overall, there are many sacrifices and trade-offs that the government has made to enhance public health and safety. Malaysia should learn from its current experience in order to handle future crises in a more consistent manner. What remains to be seen are the long-term consequences of the measures that have been taken during the pandemic. It is not yet known whether the economic impacts of the MCO will be manageable. Although the Malaysian government has continued to provide economic stimulus and financial assistance packages, these solutions are not sustainable. The government will thus need to consider what it can do to help sustain economic growth, not only by maximizing its comparative advantage, but also by ensuring that it remains actively engaged with international markets and sustains international supply chains.

\section{Conclusion}

Malaysia provides an interesting case study of how a professional and wellestablished civil service can hold a country together during the COVID-19 outbreak, even in times of political crisis. Although ministerial posts were changing hands and newly appointed ministers were tasked with facing the national crisis, consultation and dependence on the civil service and experts provided Malaysia with the means to tackle the pandemic. It is still important to note that at the time of writing Malaysia remains under the restrictions of a RMCO. Several new clusters of infections have been detected and are being closely monitored by the government. The government has also imposed quarantine requirements for all travellers coming into Malaysia as well as those travelling between so-called 'red-zone' states.

The COVID-19 crisis shows that the issue of migrant workers in Malaysia remains a challenge. Although these workers have received healthcare from the public hospitals, they will still face legal punishment, which includes immediate deportation back to their home country. In terms of economic assistance, the well-being of migrant workers is mostly dependent on whether the company they work for has taken steps to ensure this. It is difficult to estimate the amount of government aid that reaches migrant workers. In the midst of this, Malaysia's political future also remains uncertain, since 
there is no clear-cut majority in parliament. It is likely that the political uncertainty will further impact and aggravate the damage that the pandemic has wrought on Malaysia's economy.

\section{References}

Al Jazeera. 2020. 'Locked Up in Malaysia's Lockdown.' Malaysia, AlJazeera, 3 July. Accessed 2 October 2020. https://www.aljazeera.com/programmes/101east/2020/07/ locked-malaysia-lockdown-200702104523280.html.

Babulal, Veena. 2020. 'Malaysia to Deport All Covid-19 Negative Undocumented Workers [NSTTV].' New Straits Times, 26 May. Accessed 25 September 2020. https://www.nst.com.my/news/nation/2020/05/595449/ malaysia-deport-all-covid-19-negative-undocumented-workers.

Bernama. 2020. 'Dewan Perniagaan Amerika minta kerajaan pertimbang semula larangan kemasukan warga AS ke Malaysia.' Astro Awani, 4 September. Accessed 5 October 2020. https://www.astroawani.com/berita-malaysia/ dewan-perniagaan-amerika-minta-kerajaan-pertimbang-semula-larangankemasukan-warga-as-ke-malaysia-258067.

Code Blue. 2020. 'Malaysia Tested 73,00o Foreigners for Coronavirus, 3.7\% Positive.' Galen Centre for Health and Social Policy, 14 August. Accessed 2 October 2020. https://codeblue.galencentre.org/2020/08/14/ malaysia-tested-7300o-foreigners-for-coronavirus-3-7-positive/.

Global Detention Project. 2020. 'Malaysia: Covid 19 Updates.' Global Detention Project, 16 April. Accessed 16 March 2021. https://www.globaldetentionproject. org/countries/asia-pacific/malaysia.

Hermesauto. 2020. 'Malaysia's Health Chief Warns against Discrimination of Migrant Workers amid Coronavirus Outbreak at Detention Centres.' The Straits Times, 25 May. Accessed 16 February 2021. https://www.straitstimes.com/asia/ se-asia/coronavirus-breaks-out-at-detention-centres-in-malaysia-healthministry-warns-against.

Jabatan Perdana Menteri. 2020a. 'Teks Ucapan Perutusan Khas Pakej Rangsangan Ekonomi Prihatin Rakyat (PRIHATIN).' Pejabat Perdana Menteri Malaysia, 27 March. Accessed 28 September 2020. https://www.pmo.gov.my/ms/2020/03/ teks-ucapan-perutusan-khas-pakej-rangsangan-ekonomi-prihatin-rakyatprihatin.

- 2020b. 'Teks Ucapan Pengumuman Lanjutan Moratorium Bantuan Bank Bersasar.' Prime Minister's Office of Malaysia, 29 July. Accessed 28 September 2020. https://www.pmo.gov.my/2020/07/teks-ucapan-pengumuman-lanjutanmoratorium-bantuan-bank-bersasar/. 
Kanyakumari. D. 2020. 'What We Learnt from the Three Biggest COVID-19 Clusters in Malaysia.' Channel News Asia, 28 July. Accessed 16 February 2021. https://www. channelnewsasia.com/news/asia/malaysia-covid-19-largest-clusters-tablightahfiz-foreign-worker-12961276.

Kaos Jr, Joseph, and Hemananthani Sivanandam. 2020. 'Govt Defends Treatment of Foreign Workers during Covid19, Including Undocumented Ones.' The Star Online, 27 May. Accessed 28 September 2020. https://www.thestar.com.my/ news/nation/2020/05/27/govt-defends-treatment-of-foreign-workers-duringcovid19-including-undocumented-ones.

Landau, Esther. 2020. 'Covid-19 Positive Migrants Quarantined at MAEPS, Reducing Risk of Spread at Depots.' NST Online (New Straits Times), 25 May. Accessed 4 October 2020. https:/www.nst.com.my/news/nation/2020/05/595259/ covid-19-positive-migrants-quarantined-maeps-reducing-risk-spread-depots.

Lim, Justin. 'Malaysia Told to Reconsider Entry Ban on Citizens of Countries with over 150,000 Covid-19 Cases.' The Edge Markets, 7 September. Accessed 28 September 2020. https://www.theedgemarkets.com/article/malaysia-toldreconsider-entry-ban-citizens-countries-over-1500oo-covid19-cases.

Loh, Foon Fong. 2020. 'Army to Assist Cops in Enforcing MCO from Sunday (March 22).' The Star Online, 20 March. Accessed 28 September 2020. https:// www.thestar.com.my/news/nation/2020/03/20/army-to-assist-cops-enforcemco-on-sunday-march-22.

Loheswar, Rathakrishnan. 2020. 'Dr Noor Hisham Says Klang Valley Covid-19 Spread under Control, CMCO and TEMCO way to go.' Malay Mail, 21 December. Accessed 17 March 2021. https://www.malaymail.com/news/malaysia/2020/12/21/ dr-noor-hisham-says-klang-valley-covid-19-spread-under-control-cmco-andtem/1933965.

Malay Mail. 2020. 'Covid-19: Foreign Missions Thank Govt for Action, Treatment for Immigration Detainees.' Malay Mail, 3 June. Accessed 16 March 2021. https:// www.malaymail.com/news/malaysia/2020/06/o3/covid-19-foreign-missionsthank-govt-for-action-treatment-for-immigration-d/1872046.

Ministry of Health. 2020a. Kenyataan Akhbar KPK 28 Februari 2020 - Situasi Terkini Jangkitan Coronavirus Disease (COVID-19) di Malaysia [Ministry of health Press Release 28 February 2020 - Latest Infection Situation on the Coronavirus Disease (COVID-19) in Malaysia]. Accessed 13 December 2020. https://kpkesihatan. com/2020/02/28/kenyataan-akhbar-kpk-28-februari-2020-situasi-terkinijangkitan-coronavirus-disease-covid-19-di-malaysia/.

-. 2020b. 'Press Statement Ministry of Health Malaysia.' Accessed 11 March 2021. http://covid-19.moh.gov.my/terkini/o52020/situasi-terkini-13-mei-2020/ Kenyataan\%2oAkhbar\%2oKPK\%2oCOVID-19\%2o(13\%2oMei\%202020)\%20 -\%2ofinal\%2o-EN.pdf. 
—. 2020c. 'Covid 19 Malaysia Updates.' COVID. Accessed 13 October, 2020. http:// covid-19.moh.gov.my/terkini.

New Straits Times. 2020. 'Govt to Subsidise Covid-19 Screening of Workers: New Straits Times.' NST Online (New Straits Times), 31 May. Accessed 4 October 2020. https://www.nst.com.my/news/nation/2020/05/596721/ govt-subsidise-covid-19-screening-workers.

Peter, Zsombor. 2020. 'Rights Groups Decry Malaysia Probe of Al Jazeera.' VOA News, 5 August. Accessed 16 March 2021. https://www.voanews.com/press-freedom/ rights-groups-decry-malaysia-probe-al-jazeera.

Rodzi, Nadirah H. 2020. 'Malaysia Raids Al Jazeera and Offices of Two Other Broadcasters in Probe on Documentary.' The Straits Times, 4 August. Accessed 19 September 2020. https://www.straitstimes.com/asia/se-asia/qatar-basedbroadcaster-al-jazeera-says-malaysian-office-raided-over-documentary.

Sandanasamy, Florida, Marja Paavilainen, and Nilim Baruah. 2020. 'COVID-19: Impact on Migrant Workers and Country Response in Malaysia.' International Labour Organization, 8 May. Accessed 2 October 2020. https://www.ilo.org/ wcmsp5/groups/public/---asia/---ro-bangkok/documents/briefingnote/ wcms_741512.pdf.

Smith, Emily Jane. 2020. "Disturbing and disappointing': Malaysia authorities block Australian journo visas.' Dateline, 7 August. Accessed 16 March 2021. https://www.sbs.com.au/news/dateline/disturbing-and-disappointing-malaysiaauthorities-block-australian-journo-visas.

Sukumaran, Tashny. 2020. 'As Malaysia Reopens, Migrants Return to the Dangers of Life in "3D".' South China Morning Post, 7 July. Accessed 3 October 2020. https://www.scmp.com/week-asia/health-environment/article/3092084/ malaysias-coronavirus-lockdown-lifts-migrant-workers.

Tan, Theng Theng, Nazihah Muhamad Noor, and Jarud Romadan Khalidi. 2020. 'Covid-19: We Must Protect Foreign Workers.' Khazanah Research Institute Discussion Paper 8/20, 5 June. Accessed 17 March 2021. http://www.krinstitute.org/assets/contentMS/img/template/editor/20200607_Discussion\%20 Paper_Covid-19_We\%2oMust\%2oProtect\%2oForeign\%2oWorkers_Rev.pdf.

Tang, Kuok Ho Daniel. 2020. 'Movement Control as an Effective Measure against Covid-19 Spread in Malaysia: An Overview.' Journal of Public Health: 1-4. https:// doi.org/10.1007/s10389-020-01316-w.

The Star. 2020. 'Reconsider Entry Ban, Malaysia Urged.' The Star Online, 4 September. Accessed 5 October 2020. https://www.thestar.com.my/news/nation/2020/09/05/ reconsider-entry-ban-malaysia-urged.

Yunus, Arfa. 2020. 'Explain Our Side of the Story, Says Dr M on Al Jazeera Report.' New Straits Times, 21 July. Accessed 16 March 2021. https://www.nst.com.my/ news/nation/2020/07/610396/explain-our-side-story-says-dr-m-al-jazeera-report. 


\section{About the Authors}

Nurliana KAMARUDDIN is Deputy Executive Director (Academic) at the Asia-Europe Institute, Universiti Malaya. She obtained her PhD in International Studies from Ewha Womans University, specializing in Development Cooperation. Her area of research includes international politics and development with a focus on ASEAN and East Asian relations. Kamaruddin was a recipient of the Korea Foundation ASEAN Fellowship (2013-2015), the POSCO TJ Park Foundation Asia Fellowship (2009-2011) and the Ewha Global Partnership Program scholarship (2006-2009). Prior to her appointment as Senior Lecturer at the Asia-Europe Institute (AEI), Nurliana was a Research Assistant at the AEI (2011-2013). Before that, she was a lecturer at the English Language Centre, Stamford College, Selangor (2009). Nurliana is the co-editor of the book ASEAN Post 5o:Emerging Issues and Challenges (Palgrave Macmillan, 2019).

Zokhri IDRIS has held several academic positions in International Relations (IR) research and teaching, and now is the Deputy Dean of Student Affairs at the Management and Science University (MSU) in Malaysia. He served as a senior faculty member in the Faculty of Business Management and Professional Studies (FBMP), MSU after completing his industrial attachment at Puncak Niaga Management Services as an assistant manager serving the Strategic Resources and Public Relations Division. His research focuses on the changing nature of diplomacy and sovereignty of developing nations, especially Malaysia. This led him to the establishment of the Eirene Research website, to explore leadership and diplomacy in International Relations. He co-founded ARUS, an avenue to nurture talent and empower Malaysian youth. Currently, he serves the Institute of Democracy and Economic Affairs, Malaysia (IDEAS) as Director of External Relations. 
